Historia Slavorum Occidentis

2017, nr 1 (12)

ISSN 2084-1213

DOI: $10.15804 / \mathrm{hso} 170102$

\title{
Marie Bláhová (Praha)
}

\section{Panovník a sacrum v raně přemyslovských Čechách (10.-12. století)}

Słowa kluczowe: przemyslidcy książęta, chrześcijaństwo, św. Wacław, monety, pieczęcie

Keywords: Přemyslid princes, christianity, St. Wenceslas, coins, seals

\begin{abstract}
The author traces the origins and the development of the Přemyslid princes' ideology, who would rely on the charisma of their predecessor on the Czech throne, Saint Wenceslas. In the historical documents, on coins and seals, she traces the development of the position and function of the oldest Czceh saint and Czech patron and the enlargement of the company of the Czech monarch's and his people's protectors after accepting Saint Adalbert and Saint Procopius.
\end{abstract}

Počátky českého přemyslovského státu se časově kryjí s přijetím a šîrením křestanství v Čechách, přemyslovský stát se nadále vyvíjel v symbióze $s$ křestanstvím ${ }^{1}$. Tato skutečnost se odráží v postavení a počínání českého panovníka,

1 K počátkům českého státu srv. především V. Novotný, České dějiny I,1. Od nejstarš̌ch dob do smrti knižete Oldřrcha, Praha 1912, passim; Z. Fiala, Přemyslovské Čechy, 2. vydání Praha 1975; M. Matła, Czechy, Poznań 2014 (= Początki Państw); z archeologického hlediska M. Lutovský, Po stopách prvních Premyslovciu, I. Zrozeni státu, Praha 2006, II. Léta krize a obnovy (972-1012): od Boleslava II. po Jaromíra, Praha 2007, III. Správa a obrana země (1012-1055): od Oldricha po Břetislava I., Praha 2008. K diskusi o existenci, či spíše „neexistenci” státu v raném středověku, která probíhá v Německu od šedesátých let 20. století a v níž se od osmdesátých let angažovali především J. Fried a H.-W. Goetz, srv. J. Jarnut, Anmerkungen zum Staat des frühen Mittelalters: Die Kontroverse zwischen Johannes Fried und Hans Werner Goetz, [in:] Akkulturation. Probleme einer germanisch-romanischen Kultursynthese 
a také v podání středověkých „historiků”, kteří o něm informují. První datovaná zpráva v nejstarším historiografickém díle, České kronice pražského děkana Kosmy († 1125), se týká právě pokřtění prvního křestanského knížete Bořivoje moravským arcibiskupem Metodějem za vlády moravského „krále” Svatopluka, údajně roku 894. Jednoznačně chybné datum má na svědomí autor kroniky, který datum křtu neznal ani nikde nenalezl a uvedl místo něho datum úmrtí „krále” Svatopluka, které našel v Kronice prümského opata Reginona ${ }^{2}$, aniž by si dělal starosti s tím, že Metoděj v té době již devět let nežil. Přesné informace o Metodějovi ostatně také ve svých pramenech nenalezl.

Symbióza profánní panovnické moci a církevní autority prolíná také celé přemyslovské dějiny. Panovník se nejen opíral o církevní činitele jako jediné znalce písemné kultury nutné pro správu státu, ale prosazoval církevní zásady jako prostředky státní správy (zákonodárství), a především využíval „posvátného” - sacrum - pro legitimaci vlastního postavení.

V blízkém okolí panovníka se od okamžiku, kdy se připravoval na přijetí křtu, pohybovali duchovní, knížecí kaplani, kteří působili nejen jako zpovědníci a duchovní rádci knížecí rodiny, ale také jako úředníci, diplomaté, rádci v politických záležitostech ${ }^{3}$, někdy i jako lékaři ${ }^{4}$. Současně vyvíjeli tlak na panovníka, aby pečoval o šíření křestanství a jeho upevnění ve všech společenských vrstvách. $\mathrm{K}$ tomu bylo zapotřebí zajistit dostatek kněží a zřídit místa, kde by se mohli věrící

in Spätantike und frühem Mittelalter, hrsg, von D. Hägermann, W. Haubrichs und J. Jarnut, Berlin - New York 2004 (= Ergänzungsbände zum Reallexikon der Germanischen Altertumskunde, Bd. 41), s. 504-509. Přehled názorů a př́slušné literatury podává rovněž W. Pohl, "Herrschaft", [in:] Reallexikon der Germanischen Altertumskunde 14, 1999, s. 443-457. Tato studie vznikla na Univerzitě Karlově v rámci programu PROGRES Q09: Historie - Klíč k pochopení globalizovaného světa.

2 Srv. L. Wolverton, Cosmas of Prague. Narrative, Classicism, Politics, Washington D.C. 2015, s. 57.

3 Např́ílad o boleslavském proboštovi a budoucím biskupovi Heřmanovi uvádí Kosmas slovy Viprechta z Grojče, že vždy byl regis in servicio constans, in commisso fidelis, in legationibus agendis fidus executor... - „v službě královské stálý, v tajemství věrný, v poselstvích spolehlivý jednatel..." Srv. Cosmae Pragensis Chronica Boemorum, ed. B. Bretholz unter Mitarbeit von W. Weinberger, MGH SRG NS II, Berlin 1923, III,7, s. 168, český překlad Kosmova kronika česká, prèl. K. Hrdina a M. Bláhová, Praha 2012, s. 155.

4 Např́klad korvejský mnich Thiddag prý ošetřoval nemocného Boleslava II., který si ho později vybral za biskupa. Srv. Die Chronik des Bischofs Thietmar von Merseburg und ihre Korveier Überarbeitung, hrsg. von R. Holtzmann, Berlin 1935, s. 468-469. K tomu V. Novotný, České dějiny I, 1, s. 647, 658 n. 
scházet a byli tam poučováni o křestanské viŕe. Panovníci proto zakládali kostely nejprve na knížecích hradech, později i mimo ně. Neznámý počet kostelů založila již první křestanská knížata ${ }^{5}$ Boleslav II. jich prý založil dvacet ${ }^{6}$. Postupně je v tom následovali i přední muži země. Biskup Dětmar po nástupu do úřadu v roce 976 prý nejprve světil kostely, na mnohých místech od věrících vystavěné7.

Konsolidující se stát za vlády Boleslava I. (935-967/972) potřeboval i vlastní církevní správu v čele s biskupem. Proto již Boleslav I. zahájil jednání s papežem a dosáhl zř́zení biskupství v Praze ${ }^{8}$. Biskup však byl v této době v podřízeném postavení ke knížeti - v podstatě byl knížecím kaplanem bez větších pravomocí kromě sakrálních úkonů. Pokus druhého pražského biskupa Vojtěcha o emancipaci od knížecí moci a prosazení církevních požadavků v české společnosti skončil neúspěchem a Vojtěchovi se stal osudným ${ }^{9}$. Teprve Vojtěchovi nástupci postupně dosáhli na panovníkovi vyhlášení církevních ustanovení jako zemských zákonů: u prŕležitosti vyzvednutí ostatků svatého Vojtěcha z hrobu v Hnězdenské katedrále a jejich přenesení do Prahy v roce 1039 vyhlásil Břetislav I. (1034-1055) v součinnosti s pražským biskupem Šebířem nařízení, která jednoznačně vyjadřovala podporu státu křestanské církvi, jejím kněžím a zásadám křestanské morálky. Tyto tzv. Dekrety Břetislavovy obsahovaly většinu požadavků, které kladl biskup Vojtěch na obyvatele země za svého episkopátu: uznávaly církevní předpisy v oblasti manželského práva, ukládaly arcikněžím, aby dávali podnět ke stíhání osob podezřelých z vraždy a ukládaly tresty za vraždu, zakazovaly provozovat

5 Cosmae Pragensis Chronica I, 15, s. 35.

6 Ibidem, 22, s. 42.

7 Ibidem, 24, s. 46.

8 Hlavní zpravodaj, pražský děkan Kosmas, připisuje sice zř́zení biskupství až Boleslavovi II., protože tento zbožný čin se nehodil do jeho koncepce Boleslava I. „Ukrutného” jako bratrovraha a vraha světce, ale minimálně počátky těchto jednání náleží Boleslavovi I. Srv. D. Třeštík, Kosmova kronika, s. $61 \mathrm{n}$.

9 Základní informace uvádějí oba nejstarší Životy svatého Vojtěcha: Św. Wojciecha biskupa i męczennika Żywot pierwszy a Św. Wojciecha biskupa i męczennika Żywot drugi napisany przez Brunona z Kwerfurtu, ed. J. Karwasińska, Pomniki Dziejowe Polski II,1-2, Warszawa 1962, 1969. Soupis literatury k osobnosti sv. Vojtěcha a př́slušným pramenům do roku 1999 uvádí A. Witkowska a J. Nastalska, Święty Wojciech - życie i kult. Bibliografia do roku 1999, Lublin 2002. Z rozsáhlé literatury srv. především H. G. Voigt, Adalbert von Prag. Ein Beitrag zur Geschichte der Kirche und des Mönchtums im zehnten Jahrhundert, Westend Berlin 1898; rovněž F. Dvorník, Svatý Vojtěch, druhý pražský biskup, Ř́m 1967; G. Labuda, Święty Wojciech. Biskup-Mięczennik. Patron Polski, Czech $i$ Węger, Wrocław 2000. 
krčmy, konat trhy a vykonávat fyzickou práci v neděli a ve svátky a pohřbívat mrtvé mimo křestanské hřbitovy ${ }^{10}$.

Břetislavův vnuk Břetislav II. (1092-1100) zase po svém nástupu na český trůn, „něco ustanovil $\mathrm{k}$ užitku církve, něco nařídil ve prospěch této země ... roznícen jsa velikou horlivostí pro křestanské náboženství, vyhnal pryč ze země všechny čaroděje, hadače a věštce, rovněž dal pokácet a spálit i háje nebo stromy, které na mnohých místech prostý lid ctil..."11.

Soudobí ideologové, vesměs intelektuálové působící v církevních institucích, zdůrazňovali v zájmu propagace křestanství a církve také - skutečné i vykonstruované - křestanské ctnosti panovníků. Tuto skutečnost lze sledovat v již zmíněné Kosmově České kronice. Když Kosmas nemohl ve svých pramenech najít konkrétní doklady, použil alespoň obecné formulace. Tak byl Boleslav II. (967/972-999) v Kosmově podání pravý opak svého otce Boleslava I. „Ukrutného”. Na rozdíl od otce v něm „... hořela pravá láska Kristova a čisté milování...”12. Byl to „muž nejkřestanštějšsí, věrící v obecnou církev, otec sirotků, ochránce vdov, utěšitel zarmoucených, milostivý príijímatel duchovních a poutníků, kostelů božích obzvláštní zakladatel” ${ }^{13}$. Byl „kníže nejvýtečnější, ... ve věcech spravedlnosti, katolické víry a křestanského náboženství nejhorlivějším vykonavatelem... Byl také $\mathrm{v}$ bojích vítězem nejvítěznějším, ale $\mathrm{k}$ přemoženým slitovníkem nejmilostivějším a zvláštním milovníkem míru. Největším bohatstvím mu byla válečná výzbroj a sladké zalíbení ve zbraních. Nebot více miloval tvrdost železa než lesk zlata;..." ${ }^{14}$.

10 Cosmae Pragensis Chronica II,4, s. 86-88; Zemský archiv v Opavě, pobočka Olomouc, Sbírka rukopisů Metropolitní kapituly Olomouc, C.O. 230. Srv. V. Vaněček, Nový text dekretu Břetislavových, Slavia antiqua 3,1951/52, s. 131-135. K této problematice rovněž M. Bláhová, Biskup Vojtěch a česká společnost, [in:] Środkowoeuropejskie dziedzictwo świętego Wojciecha. Redakcia naukowa A. Barciak, Katowice 1998, s. 71-87.

11 ... quedam ad utilitatem ecclesie decernens, quedam ob commoditatem huius terre instituens ... christiane relligionis zelo succensus nimio, omnes magos, ariolos et sortilegos extrusis regni sui e medio, similiter et lucos sive arbores, quas in multis locis colebat vulgus ignobile, extirpavit et igne cremavit... Cosmae Pragensis Chronica III,1, s. 161; český překlad Kosmova kronika, s. $148 \mathrm{n}$.

12 ... in quo verus Christi fervebat amor et pura dilectio... Cosmae Pragensis Chronica I,21, s. 42; Kosmova kronika, s. 45.

13 _ - - erat autem iste princeps ... vir christianissimus, fide catholicus, pater orphanorum, defensor viduarum, gementium consolator, clericorum et peregrinorum pius susceptor, ecclesiarum Dei precipuus fundator. Cosmae Pragensis Chronica I,22, s. 42; Kosmova kronika, s. 46.

$14 . .$. excellentissimus princeps... quia, que iusticie, que catholice fidei, que christiane religionis 
Tento oslavný nekrolog vložil Kosmas do své kroniky i přesto, že Boleslav II. přispěl k odchodu a nakonec i smrti biskupa Vojtěcha a že nezabránil vyvraždění jeho rodiny - což Kosmas ovšem omluvil dočasnou neschopností knížete vládnout ${ }^{15}$.

Snad všemi ctnostmi oplýval Břetislav I. Na vojně vynikal statečností, tělesnou silou převyšoval Samsona, moudrostí předčil Šalomouna. V bitvách vždy vítězil, oplýval bohatstvím, rozdával dary, ${ }^{16}$ byl rozumný, měl bystrý úsudek v zákonech božských i ve světských soudech, byl štědrým dárcem almužen a milostivým prríznivcem kostelů nebo vdov ${ }^{17}$. Spytihněv II. (1055-1061) byl prý především krásný, ve vážné chvíli byl prozíravý, především však v postní čas rozdával almužny v domě mnichů nebo kanovníků, účastnil se bohoslužeb, prodléval na modlitbách... ${ }^{18}$. O vlastnostech svých současníků na knížecím stolci se Kosmas již př́liš̌ nevyjadřuje. Jen o Břetislavovi II. ř́ká, že vždy ctil a miloval jediného a pravého boha. „...byl knížetem váženým, vưdcem v poli oblíbeným a bojovníkem ve zbrani nepřemožitelným" ${ }^{19}$.

Křestanské náboženství nebylo obyvatelům země vnucováno pouze pravidelnou bohoslužbou, kázáním a uměleckou výzdobou v kostelech, kde nástěnné malby, tympanony, sloupové hlavice i plastiky představovaly pro negramotné

sunt, erat ardentissimus executor ... Fuit eciam ... in preliis victoriosissimus victor, sed victis clementissimus indultor atque precipuus pacis amator. Cui erat maxime opes bellica instrumenta et dulcia armorum studia. Nam plus diligebat ferri rigorem quam auri fulgorem... Cosmae Pragensis Chronica I,32, s. 57; Kosmova kronika, s. 58.

15 Cosmae Pragensis Chronica I,29, s. 53: ...tunc temporis dux non erat sue potestatis, se comitum... Tato pasáž zřejmě odkazuje na nemoc knížete, o níž se zmiňuje Dětmar Merseburský. Srv. Die Chronik des Bischofs Thietmar von Merseburg VII,56, s. 468-469.

16 ...Quippe hanc virtutum obtinuit accumulationem, ut in rebus bellicis strennuitate precelleret Gedeonem, corporis viribus exsuperaret Samsonem, quadam speciali prerogativa sapientie preiret Salomonem. ... in omnibus preliis victor existeret ..., auro et argento locuplecior esset regibus Arabie et undique inexhaustis affluens divitiis atque in largiendis muneribus non deficiens. Cosmae Pragensis Chronica II,1, s. 82; Kosmova kronika, s. 87.

17 ... Quante autem dux iste Bracizlaus frugalitatis vel quante discretionis in divinis legibus et humanis iudiciis aut quam largus dator elemosinarum et quam pius fautor ecclesiarum sive viduarum fuerit... Cosmae Pragensis Chronica II,13, s. 103; Kosmova kronika, s. 103.

18 ... Vir bonus et talos a vertice pulcher ad imos erat. ; ..., semper quadragesimali tempore ... in claustro elemosinis vacabat, divinis officiis instabat, vigiliis et orationibus inherebat..., Cosmae Pragensis Chronica II,14, s. 103; II,16, s. 107 n., Kosmova kronika, s. 104, 107.

19 ...Erat enim princeps spectabilis, dux in castris acceptabilis, miles in armis inexpugnabilis... Cosmae Pragensis Chronica III,1, s. 161; Kosmova kronika, s. 149. 
křestany biblické dějiny, události ze života Krista a světců, i tresty pro nevěřící a hříšníky ${ }^{20}$, a panovnickými nařízeními. Pro prosazení a upevnění křestanství využívali panovník a jeho duchovní rádci všech možných prostředků. Na každého obyvatele prrímo útočily křestanské symboly na mincích, které bral denně do ruky. Kaplice a křriže byly nejběžnějšími obrazy na českých denárech od 10 . století. Občas je nahradilo nebo $\mathrm{k}$ nim přibylo i vyobrazení Krista ${ }^{21}$.

Organizace církve a prosazení církevních zásad a křestanského učení v životě společnosti formou knížecích nařízení (zákonů) a působením slova kněží i křestansky laděných obrazů $\mathrm{v}$ církevním i profánním prostředí vytvářely vnější rámec pro uplatnění sacra $\mathrm{v}$ panovníkově politice a jeho využití v panovnické propagandě a legitimaci. „Posvátné” v ideologii českého státu reprezentovaného panovníkem se formovalo souběžně s prosazováním křestanství. Hlavní role v něm připadla knížeti Václavovi (923/924-929/935)22.

Objektivní informace o životě čtvrtého křestanského českého knížete prameny nepřinášejí. Kromě stručných zpráv o Václavově narození a mučednické smrti v Kosmově kronice ${ }^{23}$ jsou k dispozici pouze hagiografické prameny - Životy sv. Václava $^{24}$. Autoři prvních životů stvořili obraz křestanského knížete zavražděného

20 M. Bláhová, Obrazové dějiny v českých zemích ve středověku, [in:] Imago narrat. Obraz jako komunikat w społeczeństwach europejskich. Pod red. S. Rosika i P. Wiszewskiego, Wrocław 2002 (= Acta Universitatis Wratislaviensis No 2478, Historia CLXI), s. 220-224, 229n.

21 Srv. E. Fiala, České denáry, Praha 1895; Z. Petráň, První ceské mince, Praha 1998; F. Cach, Nejstarš́ české mince. I. České denáry do mincovni reformy Brètislava I., Praha 1970, II. České a moravské denáry od mincovni reformy Bretislava I. do doby brakteátové, Praha 1972; J. Šmerda, Denáry české a moravské. Katalog mincí českého státu od X. do počátku XIII. století, Brno 1996. K mincím Boleslava II. rovněž L. Nekvapil, Denárový poklad z Chýště. Katalog unikátního nálezu českých mincí z konce 10. století, Pardubice 2016.

22 Z rozsáhlé literatury o knížeti Václavovi srv. především F. Dvorník, Život svatého Václava, Praha 1929; P. Kubín a kol., Svatý Václav. Na památku 1100. výročí narozeni knižete Václava Svatého, Praha 2010; V. Vaníček, Svatý Václav, Praha-Litomyšl 2014. K funkci sv. Václava $v$ ideologii českého státu srv. prèedevším D. Trèstík, Václav jako věčný panovník a český stát v raném stréedověku, Dějiny a současnost 5, 1958, s. 35-48; R. Nový, Státní ideologie raně feudálnich Čech, in: $Z$ českých dějin, Praha 1966, s. 23-33; týž, Premyslouský stát 11. a 12. století, Praha 1972, s. 171-175; F, Graus, Lebendige Vergangenheit. Überlieferung im Mittelalter und in den Vorstellungen vom Mittelalter, Köln-Wien 1975, s. 159-173; L. Wolverton, Hastening toward Prague. Power and Society in the Medieval Czech Lands, Philadelphia 2001, s. 147-149.

23 Cosmae Pragensis Chronica I, 15, s. 34 n., I,17, s. 35 n.

24 Přehled podává J. Nechutová, Latinská literatura českého středověku do roku 1400, Praha 2000, s. 39-52. Z nejnovější literatury ke svatováclavským legendám srv. především J. Na- 
bezbožným bratrem a usurpátorem trůnu. Václava představují jako člověka, který od útlého věku toužil po vzdělání, cvičil se v žaltáři. Jako panovník byl moudrý a pravdomluvný, na soudu spravedlivý, vyhýbal se vynášení rozsudků smrti, boural vězení, kácel šibenice, vynikal soucitem $\mathrm{k}$ sirotkům, byl otcem vdov, utěšitelem raněných, krmil hladovějící, napájel žíznivé, odíval nahé svými šaty, navštěvoval nemocné, pohřbíval mrtvé, vlídně přijímal cizince, uctivě posluhoval kněžím a klerikům, zbloudilým ukazoval cestu pravdy, osvědčoval pokoru, trpělivost, mírnost a lásku. Násilím prý nikomu na světě nic neodňal ${ }^{25}$. V postním čase putoval pě̌ky a bos do kostelů, pod královským oděvem nosil žíněnou košili. Osobně sklízel a mlel obilí, v noci chodil pro vodu a pekl oplatky, sklízel hrozny na své vinici a lisoval víno pro bohoslužby. Neustále při sobě nosil knižku, v níž si při každé vhodné prŕíležitosti četl. Odmítal účastnit se pohanských obřadů. Jako kníže chtěl prý především sloužit bohu a pečovat o rozkvět křestanského náboženstvíi ${ }^{26}$.

Jen mimochodem se čtenář dozví, že tento kníže měl také vojsko, které prý vybavoval nejen zbraněmi, ale i nejlepším oděvem, trestal neukázněné vojáky, a že vedl - vždy vítězné - bitvy ${ }^{27}$.

Tohoto zbožného muže, jenž prý dokonce toužil po mnišském rouše, se jeho „mladší a horšri” bratr jménem Boleslav rozhodl zahubit. Pozval ho na hostinu, a když Václav šel po hostině na ranní mši, dal ho zavraždit ${ }^{28}$.

Bratrovražda zjitřila náladu ve společnosti. Následovaly politické čistky a obecná nejistota. Rozrušení lidé přicházeli $\mathrm{k}$ hrobu zavražděného a nelze se divit, že tam viděli zázraky, o nichž se pak širíily zprávy po celé zemi. Nový panovník ve snaze uklidnit situaci dal Václavovy tělesné pozůstatky přenést do ústředního kostela, tedy kostela sv. Víta na Pražském hradě. Zde lze věrit kronikárii, že proto, aby zázraky, pokud by bůh nějaké zjevil, nebyly přičítány Václavovi, ale patronu kostela, svatému Vítu ${ }^{29}$.

Tato snaha byla ovšem marná. Úcta $\mathrm{k}$ Václavovi narůstala a samotné přenesení do hlavního chrámu bylo možno interpretovat jako Václavovu kanonizaci ${ }^{30}$.

stalska-Wiśnicka, Rex martyr. Studium źródtoznawcze nad legendą hagiograficzna św. Wactawa (X-XIV w.), Lublin 2010 (starší literatura na s. 362-398).

25 Srv. především Život sv. Václava (Crescente fide christiana), ed. J. Truhlár, Prameny dějin českých / Fontes rerum Bohemicarum I, Praha 1873, s. 183 n.

26 Život sv. Václava, s. 185.

27 Ibidem, s. 185.

28 Ibidem, s. $186 \mathrm{n}$.

29 Cosmae Pragensis Chronica I,19, s. 38.

$30 \mathrm{~K}$ problematice kanonizace světců před zavedením kanonizačního procesu v Ř́mě srv. 
Již saský kronikář Widukind, který psal své Tři knihy saských dějin v šedesátých letech 10. století, prý slyšel o zázracích, které činil - nejmenovaný - „král” Čechư $^{31}$. Václavův hrob v Praze přitahoval poutníky nejen z Čech. Budoucího pražského biskupa Dětmara poznal kníže Boleslav II. během jeho pouti do Prahy, jistě k hrobu svatého Václava ${ }^{32}$. O novém světci byly skládány legendy v Čechách i v jiných zemích ${ }^{33}$. V poslední čtvrtině 10 . století bylo již Václavovo jméno uváděno v kalendáŕích. Nejstarší doklad je v sakramentáři z let 983-994 uloženém v knihovně kapituly ve Veroně ${ }^{34}$. V Čechách se prosazoval výroční den Václavovy vraždy jako svátek ${ }^{35}$. Nejpozději ve druhé polovině 11 . století česká knížata na tento den svolávala velmože na kolokvium do Prahy a pořádala pro ně slavnosti. Břetislav II. při té př́ležitosti vydal zákony na podporu křestanství ${ }^{36}$. Václavovi byly zasvěcovány kostely. Vedle Pražského kostela, kde bylo Václavovo jméno připojeno k původnímu patrociniu sv. Víta, mu byl zasvěcen především kapitulní kostel ve Staré Boleslavi vysvěcený 19. května 1046³. Pražský hrad s hrobem svatého Václava v již biskupském kostele ${ }^{38}$ se stal „Hradem svatého Václava” -

O. Krafft, Papsturkunde und Heiligsprechung. Die päpstlichen Kanonisationen vom Mittelalter bis zur Reformation. Ein Handbuch, Köln-Weimar-Wien 2005, s. 15-18.

31 Widukindi monachi Corbeiensis Rerum gestarum Saxonicarum libri tres, edd. H.-N. Lohmann, P. Hirsch, MGH SRG in usum schol., 5. vydání Hannover 1935, I,35, s. 50n. K prosazování náboženské úcty ke sv. Václavovi srv. V. Ryneš - J. Hásková, $K$ počátkưm svatováclavského motivu na českých denárech, Numismatické listy 22, 1967, s. 145-152.

32 Cosmae Pragensis Chronica I,23, s. 44.

33 Jednu z nejstarších latinských legend napsal mantovský biskup Gumpold, další (první recenze legendy Crescente fide) vznikla v Bavorsku. Srv. zde výše, pozn. 24.

34 Srv. F. X. Stejskal, Svatý Václav, Praha 1925, s. 143; V. Ryneš - J. Hásková, K počátkưm svatováclavského motivu na českých denárech, Numismatické listy 22, 1967, s. 146.

35 Srv. S. Adalberti Pragensis episcopi et martyris Vita altera, auctore Brunone Querfurtensi, ed. J. Karwasińska, Monumenta Poloniae Historica, Series nova, Tomus IV, fasc. 2, Warszawa 1969, kap. XXI, s. 27.

36 Cosmae Pragensis Chronica III, 1, s. 160 n.

37 Srv. Z. Boháč, Patrocinia kostelů prì nejstaršich klästerech a kapitulách v českých zemích, Historická geografie 5, 1970, s. 51-77; týž, Patrocinia románských kosteli̊ v Čechách, Historická geografie 8, 1972, s. 31-52 (soupis Václavských kostelů na s. 43); týž, Patrocinia jako jeden z pramenů $k$ dějinám osídlení, Československý časopis historický 21, 1973, s. 369-388. 38 Z bohaté literatury o založení pražského biskupství srv. především V. Novotný, České dèjiny I,1, s. 583-592, 609-611; Z. Fiala, Dva kritické př́spèvky ke starým dèjinám českým, Sborník historický 9, 1962, s. 53-63; D. Třeštík, $K$ založeni pražského biskupství v letech 968-976: pražská a rezenská tradice, in: Vlast a rodný kraj v dile historika. Sborník prací žákủ 
Castrum sancti Wenceslai, jak ho nazval papež Řehoř VII. ve dvou listinách z roku $1074^{39}$.

Čechy tak dostaly svého prvního světce, a to svatého panovníka, jakého měli již několik staletí Frankové, Burgundané či Angličané.

Řadu svatých panovníkư ${ }^{40} \mathrm{v}$ křestanské církvi zahájil první křestanský franský král Chlodvík I. (cca 465-511). Následovali ve franské říši Gunthram (545-592), Sigebert III, (cca. 630-656/660), Dagobert II. (králem 676-679), v Burgundsku první král-mučedník Zikmund (516-524). Rovněž první pokřtěný panovník Northumbrie Edwin (cca 586-632/33) se ocitl na křestanském Pantheonu, stejně jako Oswald z Northumbrie (604-642) nebo Oswin (zemřel 651) a mnoho dalších. Václav se řadí mezi panovníky-mučedníky, tedy panovníky, kteří byli zavražděni, př́ípadně též zrazeni, jako burgundský král Zikmund, anglický král Edward (cca 962-978) nebo později dánský Kanut (vládl 1080-1086), na rozdíl od mnišských panovníků nebo panovníků padlých v řádném boji ${ }^{41}$.

Český kníže nebyl, na rozdíl od západoevropských korunovaných králů, pomazaným panovníkem, jemuž by církevní obřad dodával sakrální charisma ${ }^{42}$. Volba a intronizace českého knížete se sice odehrávala za př́ítomnosti světských i duchovních předáků, ale bez církevního obřadu ${ }^{43}$. „Sacrum” dodával knížeti právě svatý Václav jako svatý panovník neustále žijící a zasahující do života komunity, z které vzešel. K Václavovi přibyl později i svatý biskup Vojtěch, který však nikdy nedosáhl takové obliby jako svatý Václav ${ }^{44}$. Již Boleslav II. umístil na

a prátel vènovaný profesoru Josefu Petráñovi, red. J. Pánek, Praha 2004, s. 179-196; D. Kalhous, Záhadné počátky pražského biskupství, in: Evropa a Čechy na konci struedověku. Sbornik př́spěvkư věnovaných Františku Šmahelovi, red. E. Doležalová - R. Novotný - P. Soukup, Praha 2004, s. 195-208 (podrobný seznam literatury je v pozn. 1, s. 195).

39 Srv. Codex diplomaticus et epistolaris regni Bohemiae, I, inde ab anno DCCCV, usque ad annum MCXCVII, ed. G. Friedrich, Praha1904-1907, č, 70 a 71, s. 74, 75.

40 K této kategorii světců srv. F. Graus, Volk, Herrscher und Heiliger im Reich der Merowinger. Studien zur Hagiographie der Merowingerzeit, Praha 1965, s. 390-435.

41 F. Graus, Volk, s. 428-430. Pokusy o obecné uznání Karla Velikého nebo Jindřicha II., panovníkủ, kteří se nezřekli světa, nepadli v bitvě ani nebyli umučení, jako světců v 11 . století byly ovšem neúspěšné (F. Graus, tamtéž, tuto skutečnost nebere na vědomí).

42 Srv. F. Graus, Volk, s. 392.

43 Popis podává Kosmas na príkladu nastolení Břetislava I. Srv. Cosmae Pragensis Chronica I, 42, s. $78 \mathrm{n}$.

44 K úctě ke svatému Vojtěchovi v Čechách srv. M. Bláhová, Biskup Vojtěch, s. 84 n. a literatura $\mathrm{v}$ pozn. 73 . 
rub svých mincí vyobrazení světce, které nejspíše představuje svatého Václava. Zatím ovšem beze jména ${ }^{45}$.

K roku 1004 (Kosmas nesprávně datuje 1002) se vztahuje první konkrétní doklad o tom, jak „svatý Václav přispěl svým ku pomoci”. Po smrti knížete Vladivoje (1002-1003) dosazeného na český trůn Boleslavem Chrabrým a po drastickém zásahu českého knížete Boleslava III. (999-1002) proti Vršovcům se Boleslav Chrabrý s podporou části české politické reprezentace sám hodlal zmocnit vlády. Přitáhl s vojskem do Čech a obsadil Pražský hrad. Protože však poskytl podporu opozici proti římskému králi Jindřichovi II. v římsko-německé říši, vytáhl Jindřich proti němu do Čech a vojensky podpořil Přemyslovce Jaromíra. Boleslav Chrabrý v této situaci Pražský hrad se svým vojskem opustil ${ }^{46}$. Podle české tradice dal podnět $\mathrm{k}$ jejich útěku bojovník z Jaromírovy družiny - Kosmas, který situaci vylíčil o více než sto let později a nebyl o událostech této doby př́iliš informován, jmenoval chybně Jaromírova bratra Oldřicha. Zvukem trubky a pokřikem postrašil Jaromírův bojovník Poláky, ty prý tehdy přepadl strach a leknutí, „Což se stalo z podivného dopuštění božího a z přispění svatého Václava”, a utekli i s Boleslavem Chrabrým - podle Kosmy Měškem - z Prahy ${ }^{47}$.

Svatý Václav od té doby zaujal trvalé místo v přemyslovské ideologii a propagandě. Kníže Jaromír umístil jeho jméno na rub svých prvních denárư ${ }^{48}$. Následoval ho v tom také kníže Oldřich (1012-1033 a 1034) ${ }^{49}$, který později, po roce 1117 , přidal i světcovo vyobrazení ${ }^{\prime 0}$. Svatý Václav na něm drží v pravé ruce

45 F. Cach, Nejstarší české mince I, č. 122-130.

46 Srv. V. Novotný, České dějiny I,1, s. 357; nověji M. Bláhová, J. Frolík, N. Profantová, Velké dějiny zemi Koruny české, I. Do roku 1197, Praha 1999, s. 352-356.

47 .... quod erat mira Dei permissio et sancti Wencezlai intercessio... Cosmae Pragensis Chronica I,36, s. 64n.; Kosmova kronika, s. 63.

48 K odrazu kultu sv. Václava na českých mincích srv. J. Hásková, $K$ státní ideologii raně feudálních Čech, Numismatické listy 29, 1974, s. 71-77; V. Ryneš - J. Hásková, Kpočátkưm svatováclavského motivu na českých denárech, Numismatické listy 22, 1967, s. 145-152. První mincí s jménem svatého Václava je F. Cach, Nejstarši české mince I, č. 246. Podobně též. č. 247-250. Jaromírovi mohly být vzorem mince sousedních území, jako byly mince bamberské, würzburské, esslingenské, salcburské či eichstättské. Srv. V. Ryneš - J. Hásková, Kpočátkưm, s. 149.

49 Srv. F. Cach, Nejstarši české mince I, č. 285-288, 291-292. K mincím knížete Oldřicha srv. J. Hásková, K státní ideologii, s. 72-76.

50 F. Cach, Nejstarši české mince I, č. 293-296. Srv. J. Hásková, K státní ideologii, s. 74. 
kříž nebo žehnás1 - Jarmila Hásková viděla ve vyobrazení svatého Václava na Oldřichových mincích vyvrcholení úcty $\mathrm{k}$ svatému předkovi, která měla sloužit především k ideovému zdůvodnění Oldřichova násilného uchopení moci ${ }^{52}$.

Svatý Václav bez atributư ${ }^{53}$, $s$ křrižem ${ }^{54}$, př́padně žehnající1 ${ }^{55}$, je vyobrazen také na mincích Břetislava I. (1035-1055). Vedle již tradičního pojetí se však na Břetislavových mincích objevuje zcela nový motiv. Světec je poprvé vyobrazen nikoli jako modlící se kněz, ale jako kníže s praporcem, symbolem knížecí moci v levici, $s$ pravicí pozdviženou $\mathrm{k}$ žehnání ${ }^{56}$.

Na reversu mincí Břetislavova nástupce Spytihněva II. (1055-1061) je opět pouze svatý Václav s kř́̌žem ${ }^{57}$.

Až do začátku šedesátých let 11. století představuje tedy svatý Václav na přemyslovských mincích především světce. Na mincích Břetislava I. je však již náznak jeho nového pojetí.

Tyto tendence byly posíleny za vlády Vratislava II. (1061-1085). Svatováclavský motiv sice zůstal na reversu Vratislavových denárů, ale vyobrazení zaznamenalo změny: svatý Václav je na Vratislavových mincích vyobrazen s kopím. Snad tato proměna pohledu na světce souvisí s politickými událostmi doby vlády Vratislava II. Vratislav se totiž aktivně angažoval v bojích o říšský trůn na straně Jindřicha IV. proti protikráli Rudolfovi z Rheinfeldenu (1077-1080). V bitvě u Flarchheimu 27. ledna 1080 ukořistilo Vratislavovo vojsko posvátné kopí, které s sebou Rudolf nosil do boje. Vratislav si vymohl na Jindřichovi IV., aby mu kopí daroval. Vratislav je pak měl nosit před sebou při slavnostních příležitostech ${ }^{58}$. Je možné, že toto kopí Vratislav zasvětil svatému Václavovi a to se stalo jeho atributem ${ }^{59}$. Toto kopí bylo

51 F. Cach, Nejstarš̌ české mince I, č. 294, 296.

52 J. Hásková, Kstátní ideologii, s. 74.

53 F. Cach, Nejstarši české mince I, č. 311, II, č. 325, 326.

54 Ibidem, č. 304, 306, 306, 316, 317; II, č. 322, 323.

55 Ibidem, č. 310; II, č. 324.

56 Ibidem, č. 305, 308. K tomu srv. V. Ryneš - J. Hásková, Kpočátkưm, s. 150.

57 Idem, Nejstarši české mince II, č. 330-332.

58 Srv. Ekkehardi Uraugiensis Chronica, edd. G. Waitz, P. Kilon, MGH, SS Vi, Hannover 1844, s. 203.

59 Srv. M. Bláhová, J. Frolík, N. Profantová, Velké dějiny, s. 439n. K funkci kopí a jeho proměně v kopí svatého Václava" srv. O. Bauer, Kopí svatého Václava, Český časopis historický 36, 1930, s. 351-359. 
využito i na mincích. Zatímco na denárech Vratislavových předchůdců byl svatý Václav vyobrazován $s$ křrižem, př́padně bez atributů, jen Břetislav mu, zatím jen zřídka, dal do ruky knížecí praporec, na Vratislavových mincích drží v pravé ruce kopi $^{60}$. Někdy reprezentuje svatého Václava pouze ruka s kopím a Václavovo jméno $\mathrm{v}$ opisu ${ }^{61}$, eventuálně kopí a koruna s Václavovým jménem ${ }^{62}$. Na jedné minci je svatý Václav vyobrazen s královskou korunou, Vratislav zase sedí na trůně s mečem v ruce ${ }^{63}$. Vratislavovy mince názorně ukazují přeměnu Václava ze světce-mučedníka ve světce-panovníka. S kopím, na němž je ovšem upevněn knížecí praporec, je svatý Václav vyobrazen také ve Vratislavově evangelistáři známém jako Kodex vyšehradsky ${ }^{64}$.

Tento vývoj se v následujícím období prosazoval stále výrazněji. Svatý Václav zasahuje do politických záležitostí, otvírá vězení a propouští vězně, pečuje o mír v zemi. V roce 1091 společně se svatým Vojtěchem způsobili dva zázraky: Nejprve osvobodili vězně z vězení. Potom bratr krále Vratislava Konrád jejich přičiněním sjednal mír mezi králem a jeho synem a zabránili tak občanské válce: „A vskutku toho času byl by býval spáchán nejhorší zločin po založení Prahy, kdyby svatá laskavost nejblahoslavenějš́ího Václava a veliké milosrdenství všemohoucího boha nebyly utišily podle přání králova povstání všech předních mužů i lidu”" ${ }^{5}$.

60 F. Cach, Nejstarši české mince II, č. 344 (denár je zjevně omylem zařazen do doby Vratislavova údělného knížectví), 345, 346, 350.

61 Ibidem, č. 348, 349, 351, 354.

62 Ibidem, č. 354.

63 Ibidem, č. 347. Podobnou korunu má Vratislav na minci č. 352.

64 Národní knihovna České republiky, rkp. XIV A 13, fol. 68 r. K rukopisu srv. především K. Stejskal, Vyšehradský kodex a jeho misto v ottonském umèní, in: Královský Vyšehrad. Sborník príspèvků k 900. výroči úmrtí prvního českého krále Vratislava II. (1061-1092), Praha 1992, 26-43; A. Merhautová, P. Spunar, Kodex vyšehradský. Korunovačni evangelistár pruního českého krále, Praha 2006. Poprvé je svatý Václav vyobrazen s kopím, ovšem bez praporce, v dnešním Wolffenbüttelském rukopisu Gumpoldovy Legendy o svatém Václavu, který byl zhotoven někdy před rokem 1006. Tento rukopis byl zhotoven pro kněžnu Emu, která přišla do Čech ze západní Evropy, což může vysvětlovat užití tohoto atributu. D. Třeštík a A. Merhautová, Die böhmischen Insignien und steinerne Thron, in: Europas Mitte um 1000. Beiträge zur Geschichte, Kunst und Archäologie, hrsg. von A. Wieczorek und H.-M. Hinz, Bd. 2, Stuttgart 2000, s. 905, tvrdí, že je na dedikačním obrazu Wolffenbüttelského rukopisu vyobrazen svatý Václav s kopím a praporcem, ale to neodpovídá skutečnosti.

65 Cosmae Pragensis Chronica II,47, s. 154 n., Kosmova kronika, s. 142. Srv. M. Bláhová, J. Frolík, N. Profantová, Velké dějiny I, s. 462 n. 
Svatý Václav zůstává nadále na panovnických mincích až do konce denárového období, mění se pouze jeho vyobrazení. Na mincích Břetislava II. je pouze světcova hlava, zatímco kníže na aversu drží v ruce kopi ${ }^{66}$, ale také je vyobrazeno poprsí s kopím ${ }^{67}$. Další výraznou změnu přinášejí denáry Bořivoje II. (1100-1107, 1109-1110, 1117-1120). Na mincích z jeho první a druhé vlády se Václav objevuje často jako jezdec na koni ${ }^{68}$, ale také jako panovník sedící na trůně s říšským jablkem v pravici, zatímco kníže na aversu mince je vyobrazen na trůně $s$ kopím v pravé ruce ${ }^{69}$. Z období Bořivojovy třetí vlády pochází denár s dvěma postavami na reversu, jedna drží v rukou meč a kř́iž, druhá biskupskou berlu. Opis je sice silně poškozen, ale nepochybně obě postavy představují sv. Václava a sv. Vojtěcha. Na aversu je vyobrazen panovník opět s mečem a kopím, na němž je však upevněn praporec ${ }^{70}$. $\mathrm{Na}$ dalších je svatý Václav s knihou a ř́šsksým jablkem ${ }^{71}$, žehnající s knihou v pravé ruce ${ }^{72}$, nebo $s$ kopím, na němž je upevněn praporec $^{73}$. Na českých mincích knížete Svatopluka (1104-1109) vystupuje svatý Václav většinou $\mathrm{s}$ mečem ${ }^{74}$, nebo jako žehnajícíi ${ }^{75}$. Na mincích Vladislava I. jako českého knížete (1109-1117, 1120-1125) je svatý Václav vyobrazen v různých podobách: jako světec $s$ křížem ${ }^{76}$, žehnající světec ${ }^{77}, s$ kostelem $^{78}, s$ hradební zdíi ${ }^{79}$, $s$ kř́žem a $s$ knihou ${ }^{80}$, ale i s knihou a kopím ${ }^{81}$, s kopím, na němž je upevněn pra-

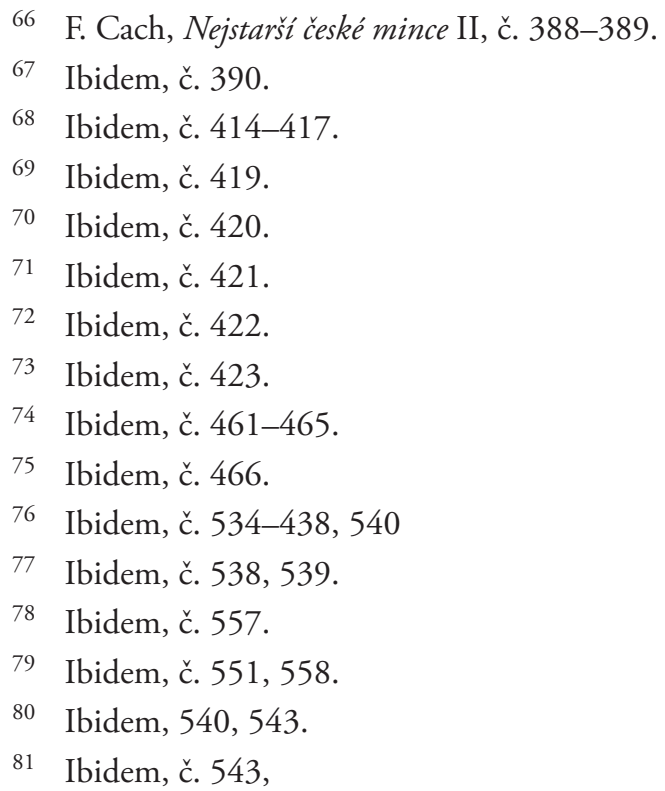


porec $^{82}$, také jako jezdec na koni ${ }^{83}$, dokonce i s mečem a štítem ${ }^{84}$, atd. Objevuje se také se svatým Vojtěchem ${ }^{85}$, který již bývá někdy uváděn i v opisu mince ${ }^{86}$.

Společenská úloha obou světců, svatého Václava a svatého Vojtěcha, vynikla na počátku vlády Soběslava I. (1125-1140). V bitvě u Chlumce, kde Soběslavovo vojsko porazilo říšského krále Lotara, který táhl do Čech na podporu Soběslavova rivala Oty Olomouckého ${ }^{87}$, podpořil české vojsko právě svatý Václav. Jeden ze stovky předáků, kteří drželi stráž u kopí svatého Václava, které s sebou vozil kníže, jak bylo tehdy zvykem, do bitev, ctnostný a urozený kaplan Vít, jenž oděn v brnění a př́lbu ,jako Achilles” držel světcovo kopí, náhle zvolal slze radostí: „Druhové a bratři, budte stálí, nebot nad hrotem posvátného kopí vidím svatého Václava, an, sedě na bílém koni a oděn bílým rouchem, bojuje za nás; i vy vizte! ${ }^{88}$ Nikdo jiný sice nic neviděl, ,jen hodným toho bylo popřáno viděti ten zázrak”, marně truchlili, slzeli a vzdychali k bohu, oči a ruce tak dlouho spínali k nebi, a volali Kyrie eleison, až je bůh vyslyšel „a svým svatým poslem Václavem, naším ochráncem, porazil nepřátele naše," jak konstatoval pražský kanovník, První po-

82 Ibidem, č. 545, 600. Kopí s praporcem jako atribut svatého Václava se objevuje také na mincích některých moravských údělných knížat. Srv. např. F. Cach, Nejstarš̀ české mince II, c. $423,474,487,506,532,533,545$.

83 Ibidem, č. 542.

84 Ibidem, č. 546,

85 Ibidem, č. 544, 547, 554, aj.

86 Ibidem, č. 547, 548.

87 V. Novotný, České dějiny I, 2, Od Břetislava I. do Přemysla I., Praha 1913, s. 567-579; M. Bláhová, J. Frolík, N. Profantová, Velké dèjiny, s. 530-532.

88 Iterum circum astantibus et custodientibus primatibus Bohemiensibus et praepositis et capallanis pene centum hastam sancti Wenceslai, inter quos unus capallanus, probus, nobili genere, nomie Vitus, qui tenebat hastam eiusdem sancti praememorati, ut mos est, indutus lorica et galea, ut Achilles, lacrimans prae gaudio clamavit ad suos: O socii et fratres, constantes estote, video enim sanctum Wenceslaum sedentem in equo albo et indutum candida veste super cacumen sacrae hastae pugnantem pro nobis, etiam et vos videte... Srv. Kanovnik vyšshradský, ed. J. Emler, in: Prameny dějin českých / Fontes rerum Bohemicarum II, ed. J. Emler, Praha 1874, 1126, s. 203 n. K tomu M. Bláhová, Vidèní kanouníka Vita. Zjitřené emoce nebo promyšlená inscenace?, [in:] Fontes ipsi sitiunt. Sborník prací k sedmdesátinám archiváre a historika Eduarda Mikuška, ed. P. Kopička, Litoměřice - Praha 2016, s. 35-41 (kaplan Vít je v titulu omylem označen jako kanovník); L. Wolverton, Hastening, s. 147-149. K př́slušnosti Prvního Kosmova pokračovatele k pražské, nikoli vyšehradské kapitule, jak se domnívali někteří historikové, srv. L. Reitinger, Psal tzv. Kanovník vyšehradský opravdu na Vyšehradě? Prvni Kosmův pokračovatel $v$ kontextu déjepisectvi premyslovského věku, Český časopis historický 113, 2015, s. 635-668. 
kračovatel Kosmův. Familia sanctí Venceslai, tedy všichni Čechové, se tak mohla radovat $\mathrm{z}$ vítězství ${ }^{89}$.

Na kopí svatého Václava byl před bitvou zavěšen také praporec svatého Vojtěcha, pro který kníže Soběslav poslal svého kaplana do vsi Vrbčany, kde byl umístěn na stěně kostela ${ }^{90}$. O vítězství knížete Soběslava a Čechů se tedy zasloužil nejen svatý Václav, ale i svatý Vojtěch.

Zásluhy obou světců i svou vděčnost rozhlásil Soběslav po celé zemi prostřednictvím mincí, které dal razit jako první po svém nástupu na český trůn. Je na nich vyobrazen kníže klečící před svatým Václavem sedícím na trůně s kopím, na němž je upevněn praporec ${ }^{91}$. Svatého Václava v různé podobě, samotného nebo s knížetem, nechal umístit i na jiné své mince ${ }^{92}$.

V nejrůznějších podobách je svatý Václav vyobrazen také na reversu mincí Soběslavova nástupce Vladislava II. (1140-1172) ${ }^{93}$. Vedle obvyklé typologie Václava s kř́ížem, se svatým Vojtěchem, kde Václav má štít nebo kopí a Vojtěch biskupskou berlu $^{94}$, je častým motivem svatý Václav s kopím, na němž je upevněn praporec ${ }^{95}$. Světec přitom někdy jede na koni ${ }^{96}$. Někdy se objevuje také se svatým Vojtěchem ${ }^{97}$.

Podobné motivy byly použity i na mincích následujících českých panovníků, Soběslava II. (1173-1178) či Fridricha (1172-1174, 1178-1189). Konráda Oty (1182, 1189-1191). Svatý Václav je na nich zobrazen jako žehnajícíis, se štítem

89 Kanovník vyšehradský 1126 , s. 203. O pojmu familia sancti Wenceslai - „čeled’ svatého Václava”, který zahrnuje všechny obyvatele českého státu, jejichž symbolickým věčným knížetem a dědicem české země je svatý Václav, pojednává Z. Fiala, Přemyslovské Čechy, s. 138. Autor, tamtéž, upozorňuje na skutečnost, že uvedená věta Prvního Kosmova pokračovatele představuje první domácí pokus o teoretické vyjádření pojmu českého národa a státu v rámci křestanské ideologie. Srv. rovněž J. Žemlička, Čechy v době knižecí (1034-1198), Praha 1997, s. 340; D. Kalhous, České země za prvnich Přmyslovců v 10.-12. století, I. dil, Čeled' sv. Václava, Praha 2011.

90 Kanovnik vyšehradský, s. 204.

91 F. Cach, Nejstarší české mince II, č. 570, 571.

92 Ibidem, č. 572-586.

93 Ibidem, č. 587-617.

94 Ibidem, č. 578, 585, 591, atd. V opisu je ovšem stále uveden pouze svatý Václav.

95 Ibidem, č. 600, 606, 607, 615-617.

96 Ibidem, č. 589, 598, 607.

97 Ibidem, č. 606.

98 F. Cach, Nejstarší české mince I, č. 639, 641. 
a s kopím ${ }^{99}$, a s praporcem ${ }^{100}$, príípadně se svatým Vojtěchem ${ }^{101}$. Na jedné minci knížete Václava (1191-1192) se objevuje světec $s$ knihou ${ }^{102}$, na jiné je svatý Václav s kopím s praporcem a se štítem na aversu a svatý Vojtěch s biskupskou berlou a s kř́ižem na reversu. Jejich jména jsou uvedena v opisu ${ }^{103}$. Na mincích Jindřicha Břetislava (1193-1197) je svatý Václav vyobrazován v různých situacích opět $s$ kopím $s$ praporcem ${ }^{104}$. Na minci Vladislava Jindřicha (1197) je naopak svatý Václav s kř́žzem a mečem ${ }^{105}$, na denárech Přemysla Otakara I. (1192-1193, 1197-1230) s mečem, křížem, kopím nebo kopím s praporcem, někdy na koni ${ }^{106}$. Objevuje se i samostatně svatý Vojtěch ${ }^{107}$. Svatý Václav v nejrůznějších podobách tedy již z českých denárů nezmizel. Jen vzácně se vedle něho, či dokonce samostatně, objevuje také svatý Vojtěch.

Politickou a ideologickou funkci svatého Václava názorně ukazují také panovnické pečeti, které jsou dochovány od čtyřicátých let 12 . století. Na rozdíl od mincí, kde omezený prostor nedovoloval konkrétně charakterizovat význam světcovy postavy a ta musela být znázorněna jen více nebo méně srozumitelným obrazem, na pečetích mohla být jeho úloha uvedena i slovy. Tak opis nejstarší dochované pečeti, knížecí pečeti Vladislava II., která byla na listině vydané mezi lety 1146-1148, zní: Pax scti Wacezlai in manu ducis Vadislaus. Na přitištěné pečeti byl vyobrazen svatý Václav sedící na trůně s kopím, na němž byl upevněn praporec, se štítem a se svatozář́i ${ }^{108}$. Na reversu Vladislavovy, již př̌ivěšené mincovní, královské pečeti má světec stejné atributy, ale opis se mění: Pax regis Vladizlai in manu sancti Vencezlai ${ }^{109}$. Obdobný opis, v němž se mění pouze

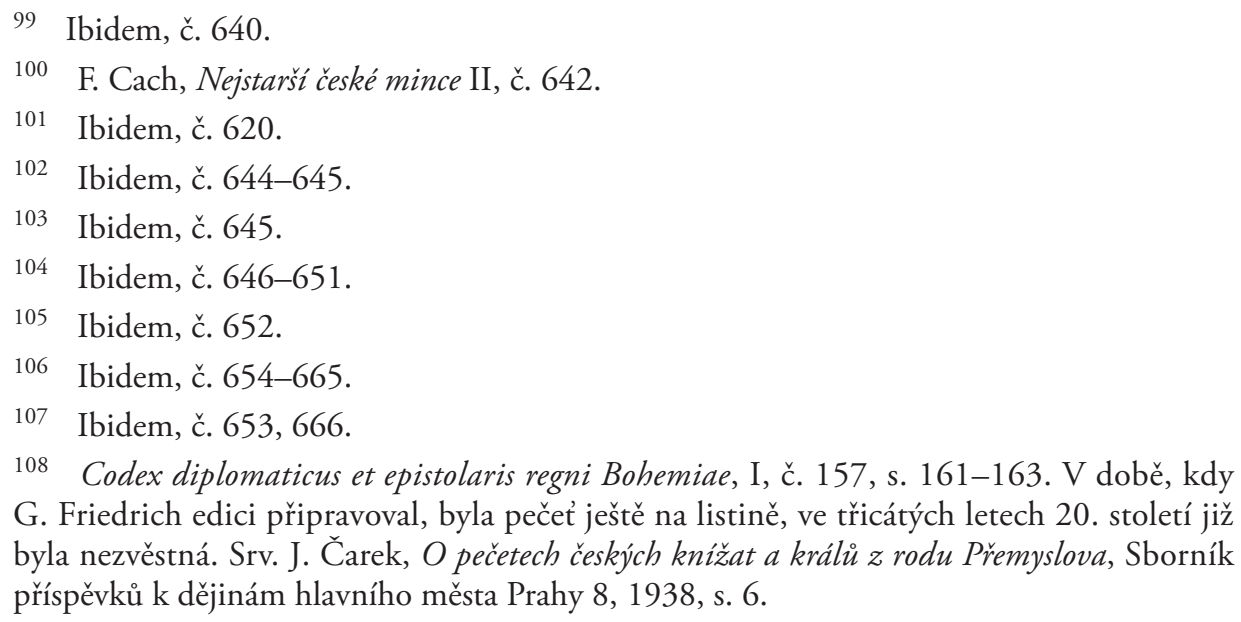

99 Ibidem, č. 640.

100 F. Cach, Nejstarš̌ české mince II, č. 642.

101 Ibidem, č. 620.

102 Ibidem, č. 644-645.

103 Ibidem, č. 645.

104 Ibidem, č. 646-651.

105 Ibidem, č. 652.

106 Ibidem, č. 654-665.

107 Ibidem, č. 653, 666.

108 Codex diplomaticus et epistolaris regni Bohemiae, I, č. 157, s. 161-163. V době, kdy G. Friedrich edici připravoval, byla pečet ještě na listině, ve třicátých letech 20. století již byla nezvěstná. Srv. J. Čarek, O pečetech českých knižat a králů z rodu Přemyslova, Sborník př́spěvků k dějinám hlavního města Prahy 8,1938 , s. 6.

109 Codex diplomaticus et epistolaris I, č. 208, s. 194-197. Srv. J. Čarek, O pečetech, s. 7. 
jméno a titul panovníka, je na přemyslovských pečetích až do 13. stoleti1 ${ }^{110}$. Jen výjimečně se objevuje jednodušší opis Sanctus Venceslaus dux ${ }^{111}$, či pouze Sanctus Venceslaus ${ }^{12}$. Svatý Václav je tedy prezentován jako ochránce míru, tedy jako ten, kdo garantuje bezpečnost, spravedlnost a pořádek v českém státě. Jeho vyobrazení jako panovníka na trůně s vojenskými atributy názorně dokládá jeho postavení „věčného panovníka” propůjčujícího moc vládnoucím knížatům ${ }^{113}$.

Svatováclavský typár byl na přemyslovských pečetích používán do dob vlády Václava I. Tento typ pečeti opustil až Přemysl Otakar II. Heslo rubových, „svatováclavských”, pečetí o míru krále v rukou svatého Václava umístil ještě na obrubu pečeti (exergue $)^{114}$. Naposledy tuto pečet použil v květnu 1277. Potom odkaz na svatého Václava z panovnických pečetí zmizel ${ }^{115}$.

V té době se již počet českých patronů rozrostl. Vedle svatého Václava zasahovali ve prospěch Čechů svatý Vojtěch a svatý Prokop, a také Pět bratří, jejichž ostatky byly přivezeny z Polska spolu s ostatky svatého Vojtěcha. Hlavní úlohu však stále měl svatý Václav. V bitvě u Kressenbrunnu 12. července 1260, nejslavnější bitvě Přemysla Otakara II., „muži, kteří drželi stráž vzadu, viděli na počátku bitvy jakéhosi ptáka, podobného v obrysech orlu, ale barvy nad sníh bělejší, se zlatou hlavou a krkem, jak nerozlučně sledoval praporec svatého Václava, kdysi knížete, vždy však patrona českého, slavného mučedníka. A zdálo se jim, jako by rostl, až pokryl celé vojsko křestanské, táhnoucí do bitvy, svým tělem a perutěmi. A téhož dne rytî́ Jan ... uviděl patrony české, ani kráčejí na jedno světlé pole $\mathrm{v}$ tomto pořadí: napřed spatřil kráčet svatého Václava, oděného v brnění se svou přilbou na hlavě, jak nese svůj meč v pochvě, ozdobený zlatem a drahými kameny, v levém podpaždí a v pravici před sebou vlastní praporec. Hned za ním šel svatý Vojtěch, jako velký a silný muž, krásně oblečen v kněžské roucho. Dále viděl svatého Prokopa jako opata s pastýřskou berlou, jak kráčel v patách za svatým biskupem, naposledy užrel pět bratří mučedníků, ani jdou ustrojeni ve vlastní suknice. Vtom uslyšel týž rytî́, že svatý Václav jasným hlasem praví

\footnotetext{
110 Srv. J. Čarek, O pečetech, s. 5-15.

111 Ibidem, s. 7-8, $12 \mathrm{n}$.

112 Ibidem, s. 10.

113 Srv. J. Žemlička, Čechy v době knižecí, s. 339-341; M. Bláhová, J. Frolík, N. Profantová, Velké déjiny I, s. 447 n.

114 J. Čarek, $O$ pečetech, s. 15.

115 Ibidem, s. $16 \mathrm{n}$.
} 
řečeným druhům své slávy: 'Mdlé je naše vojsko, spějme hned před tvář boží.' Po těch slovech rozvinul svůj praporec proti nepřátelům a ti byli hned spatřeni, jak se všude dávají na útěk" ${ }^{116}$.

\section{Shrnutí}

Česká knížata, která nevládla sama vlastním posvátným charismatem, v záležitosti panovnické legitimace a v panovnické ideologii a propagandě spoléhala na svého předchůdce na českém trůně a současně světce, svatého Václava. O charisma svatého Václava se opírala v bitvách, využívala ho však také na mincích a na pečetích. Svatý Václav se objevil na přemyslovských mincích nejpozději za knížete Jaromíra, možná již za Boleslava II. Na Boleslavových mincích je světec bez jména, na Jaromírových mincích byl svatý Václav reprezentován naopak pouze jménem. Na mincích knížete Oldřicha se již vedle nápisových mincí objevilo i vyobrazení světce. Svatý Václav byl zobrazován jako světec a patron hlavního kostela v Čechách, pražského biskupského kostela. Byl znázorňován s kř́ižem, př́ípadně jako žehnající. Tento typ mincovního reversu používal i kníže Břetislav I., ale vedle něho se, zatím jen zř́ídka, objevuje vyobrazení svatého Václava $s$ praporcem. Světec tak začíná nabývat politického charakteru.

116 ... quidam viri, qui a tergo ad custodiam exercitus fuerant deputati, imminente proelio referunt se vidisse quandam avem in lineamentis ad modum aquilae figuratam, sed in colore nive candidiorem, habentem aureum caput et collum, vexillum beati Wenceslai quondam ducis, semper vero patroni Bohemorum, inclyti martyris, inseparabiliter prosequentem; que passim visa est eisdem crescere, quoad usque ad pugnam procedentem universum corpore et plumis cooperuit exercitum christianum. Eodem etiam die ... Johannes miles ... vidit patronos Bohemiae gloriosos ad quendam campum lucidum tali ordine procedentes, primum conspicit procedentem sanctum Wenceslaum lorica indultum, habentem galea sua in capite, gestantem gladium suum in vagina auro et gemmis ornata sub ascella sinistra, in dextra vero manu proprium vexillum praeferentem; quem immediate sanctus Adalbertus, veluti vir magnus et robustus, decenter ornatus pontificalibus, sequebatur. Post haec vidit beatum Procopium, quasi abbatem cum suo baculo pastorali sanctum pontificem a vestigio commitantem; novissime cernit sequi quinque fratres martyres, quasi propriis tunicis vestitos. Tunc idem miles audivit sanctum Wenceslaum praedictis gloriae suae consortibus sic clara voce dicentem: debilis est noster exercitus, ad dei praesentiam mox tendamus. Quod dicto, vexillum suum contra hostes extendit, qui statim in fugam universaliter visi sunt conversi... Druhé pokračováni Kosmovo 1260, in: Pokračovatalé Kosmovi VI. Príběhy krále Přmysla Otakara II., in: Prameny dèjin českých / Fontes rerum Bohemicarum II, s. 318 n., český překlad Pokračovtelé Kosmovi, přeložili V. V. Tomek, K. Hrdina, M. Bláhová, red. M. Bláhová, Z. Fiala, Praha 1974, s. 128 n. 
K další fázi proměny svatého Václava v politického světce došlo za Vratislava II., kdy se jako světcův atribut začalo prosazovat kopí. Možná to, které Vratislav II. získal v bitvě u Flarchheimu. Za vlády Vladislava I. se vedle svatého Václava objevil na mincích také svatý Vojtěch. Úcta k Vojtěchovi narůstala i za jeho nástupce. V bitvě u Chlumce 1126 svatý Václav v představách Čechů bojoval za vojsko Soběslava II. Na jeho kopí byl upevněn praporec svatého Vojtěcha. Praporec svatého Vojtěcha upevněný na kopí svatého Václava se stal od té doby téměř stálým atributem svatého Václava. Svatý Václav-mučedník tak stále výrazněji nabýval podoby panovníka a bojovníka, bojujícího již také s přispěním svatého Vojtěcha. V pojetí oficiální propagandy svatý Václav pomáhal panovníkovi a jeho lidu v boji, zajištoval svému lidu i jeho panovníkovi „mír”. „Mír” panujícího knížete, tedy bezpečnost, právo a spravedlnost ${ }^{117}$ těch, jimž vládl pozemský kníže, byly v rukou svatého Václava: Pax ducis... in manu sancti Wenceslai - „mír knížete .... je v rukách svatého Václava”, jak hlásaly opisy panovnických pečetí. Václav jako „věčný panovník” propůjčoval panovnickou moc vládnoucímu knížeti a zajištoval „mír”, těm, jimž kníže vládl. Takovýto panovník pečuje o mír, vyhrává bitvy, v nouzi přichází na pomoc svému lidu. Družina ochránců českého panovníka a Čechů se ve dvacátých letech 12. století rozrostla o svatého Vojtěcha, a na počátku šedesátých let 13 . století i o svatého Prokopa. Hlavním a trvalým ochráncem Čechů však byl svatý Václav.

Prof. PhDr. Marie BlÁHová, DrSc.,

Katedra pomocných věd historických a archivního studia

Filozofická fakulta, Univerzita Karlova, nám. Jana Palacha 2, 116-38 Praha 1

marie.blahova@ff.cuni.cz

117 K významu termínu pax (mír) ve středověku srov. především H.-J. Becker - J. Hödl, Friede, w: Lexikon des Mittelalters 4, München 1989, s. 919-921; W. Janssen, Frieden, w: Geschichtliche Grundbegriffe, edd. O. Brunner, W. Conze, R. Koselleck, 2, Stuttgart 1975 , s. 543-591; př́spěvky v publikaci Träger und Instrumentarien des Friedens im hohen und späten Mittelalter, ed. J. Fried (= Vorträge und Forschungen 43), Sigmaringen 1996. 


\section{The monarch and the sacrum in the early Přemyslid Bohemia $\left(10^{\text {th }}-12^{\text {th }}\right.$ century)}

The origins of the Czech Přemyslid state overlap time wise with the acknowledgement and proliferation of Christianity in Bohemia, further on, the Přemyslid state develops in symbiosis with Christianity. This fact is reflected in the Czech monarch's position and conduct, and also in the „historians'” presentation informing about it. The symbiosis between the profane power of the monarch and the Church's authority is also integrated in the Přmyslid era. Not only did the monarch rely on the representatives of the Church as the only experts in written culture, needed for the state administration, but the Czech princes, who wouldn't govern through their own sacred charisma, relied on their predecessor on the Czech throne and a saint at the same time, Saint Wenceslas, when it came to the matters of ruler's legitimacy and the monarch's ideology and propaganda. They relied on the Saint Wenceslas' charisma during battles, but they would use him for propaganda on coins and seals as well. Saint Wenceslas appeared on Přemyslid coins during the reign of Jaromír at the latest. Another phase of the Saint Wenceslas' change into political saint took place during the reign of Vratislaus II, when a spear became the saint's attribute. In the battle of Chlumec in 1126 he had the Wenceslas' spear with the St. Adalbert of Prague's flag. Since then, this has become a permanent attribute of Saint Wenceslas. According to the official propaganda, Saint Wenceslas helped the monarch and his people in battle, ensured "peace" for the people and their monarch. The "peace” of the ruling prince, meaning the security, law and justice for those ruled by living prince, were all in the hands of Saint Wenceslas, as the transcriptions of the monarch's seals claimed. Wenceslas as the „eternal ruler" bestowed his power to the ruling prince and ensured the „peace” for those ruled by the prince. This prince would take care of the peace, win the battles, come to help his people in need. The company of the protectors of the Czech monarch and the Czechs grew in the twenties in the $12^{\text {th }}$ century while accepting Saint Adalbert of Prague and Sanit Procopius in the beginning of the sixties in the $13^{\text {th }}$ century. However, Saint Wenceslas became the main and permanent protector of Czech people. 